\title{
Association of Plasminogen Activator Inhibitor I (PAI-I) 4G/5G Polymorphism and Susceptibility to SLE in Egyptian Children and Adolescents: A Multicenter Study
}

This article was published in the following Dove Press journal:

Journal of Inflammation Research

Aly A Yousef, ' Faisal Y Mohamed, (D) ${ }^{2}$ Naglaa F Boraey, ${ }^{3}$ Nagwa E Akeel, ${ }^{4}$ Attia A Soliman, ${ }^{4}$ Nevin M Waked, ${ }^{5}$ Mustafa IA Hashem, ${ }^{4}$ Hassan Shehata, ${ }^{4}$ Dalia S Fahmy, ${ }^{6}$ Ali Ismael, ${ }^{7}$ Lamya M Ibrahim, ${ }^{8}$ Mohamed AM Ibrahim, ${ }^{9}$ Hanan F Salem, ${ }^{10}$ Sherif M Yousry, ${ }^{11}$ Sherif $F$ Osman, ${ }^{12}$ Rania A Fouad, ${ }^{13,14}$ Eman T Enan, ${ }^{15,16}$ Mohammed A Attia, ${ }^{17,18}$ Mona R Afify, ${ }^{19}$ Nancy MS Zeidan, ${ }^{20}$ Mohamed Nashat ${ }^{21}$

'Department of Pediatrics, Faculty of Medicine, Helwan University, Helwan, Egypt; ${ }^{2}$ Department of Pediatrics, Faculty of Medicine, Ain-Shams University, Cairo, Egypt; ${ }^{3}$ Department of Pediatrics, Faculty of Medicine, Sohag University, Sohag, Egypt; " Department of Pediatrics, Faculty of Medicine, Zagazig University, Zagazig, Egypt ${ }^{5}$ Department of Pediatrics, Faculty of Medicine,

October 6 University, October 6, Egypt; ${ }^{6}$ Department of Rheumatology, Faculty of Medicine, Zagazig University, Zagazig, Egypt; ${ }^{7}$ Department of Internal Medicine, Faculty of Medicine, Zagazig University, Zagazig, Egypt;

${ }^{8}$ Department of Clinical Pathology, Faculty of Medicine,

Mansoura University, Mansoura, Egypt; ${ }^{9}$ Department of Clinical Pathology, Faculty of Medicine, Sohag University, Sohag, Egypt; ${ }^{10}$ Department of Anesthesia, Faculty of

Medicine, Banha University, Banha, Egypt; "Department of Clinical Pathology, Faculty of Medicine, Cairo

University, Cairo, Egypt; ${ }^{12}$ Department of Radiology,

Texas Tech University Health Sciences Center, El Paso,

TX, USA; ${ }^{13}$ Department of Medical Biochemistry,

College of Medicine, EI-Mareefa University, Riyadh, Kingdom of Saudi Arabia; ${ }^{14}$ Department of Medical Biochemistry, Faculty of Medicine, Zagazig University, Zagazig, Egypt; ${ }^{15}$ Department of Pathology, College of Medicine, El-Mareefa University, Riyadh, Kingdom of Saudi Arabia; ${ }^{16}$ Department of Pathology, Faculty of Medicine, Mansoura University, Mansoura, 35516, Egypt; ${ }^{17}$ Department of Clinical Pharmacology, College of Medicine, El-Mareefa University, Riyadh, Kingdom of Saudi Arabia; ${ }^{18}$ Department of Clinical Pharmacology, Faculty of Medicine, Mansoura University, Mansoura, 355 16, Egypt; ${ }^{19}$ Department of Medical microbiology and Parasitology, Faculty of Medicine, University of Jeddah, Jeddah, 21589, Saudia Arabia; ${ }^{20}$ Department of Pediatrics, Faculty of Medicine, Cairo University, Cairo, Egypt; ${ }^{21}$ Department of Pediatrics, Faculty of Medicine, Aswan University, Aswan, Egypt

Correspondence: Faisal Y Mohamed

Faculty of Medicine, Ain-Shams University, Cairo, Egypt Tel +201 II 3363638

Email Faisalyousef69@gmail.com
Background: Plasminogen activator inhibitor-1 (PAI-1) is a key molecule residing at the nexus between thrombosis and inflammatory processes. Recently, PAI-1 and its gene expression have emerged as a potential candidate for autoimmune disorders such as SLE.

Objective: To investigate whether the PAI-1 4G/5G polymorphism at position -675 could be a genetic marker for susceptibility to childhood-onset SLE and development of lupus nephritis among Egyptian children and adolescents.

Methods: Three hundred fifty patients diagnosed with childhood-onset SLE and 350 wellmatched healthy controls were included in this multi-center study. All subjects were genotyped for the PAI-1 promoter 4G/5G polymorphism at position -675 using PCR- restriction fragment length polymorphism (RFLP). Serum PAI-1 levels were measured by ELISA.

Results: The PAI-1 (- 675) 4G/4G genotype was more represented in c-SLE patients, as compared to the control group (38\% vs $23 \%$; OR $=2.7$; [95\% CI: $1.47-2.9$ ]; $P<0.001$ ). Patients carrying the PAI-1 4G/4G genotype or 4G allele were more likely to develop lupus nephritis (OR: 3.38; [95\% CI: 1.9-5.9]; $P<0.001$, for the 4G/4G genotype and OR: 2.6; [95\% CI: 1.85-3.67]; for the 4G allele; $P<0.01)$. The PAI-1 4G/4G genotype was associated with higher PAI-1 serum concentrations (mean; $86.6 \pm 22.7 \mathrm{ng} / \mathrm{mL}$ ) as compared to those with a $4 \mathrm{G} / 5 \mathrm{G}$ genotype (mean; $48.3 \pm 16.5 \mathrm{ng} / \mathrm{mL}$ ) and the lowest for the $5 \mathrm{G} / 5 \mathrm{G}$ genotype (mean; $34.7 \pm 11.4 \mathrm{ng} / \mathrm{mL}) ; P=0.004$.

Conclusion: The PAI-1 4G/5G polymorphism may confer susceptibility to childhood-onset SLE and development of lupus nephritis among Egyptian children and adolescents. Moreover, the PAI-1 4G/4G genotype and 4G allele were associated with higher PAI-1 serum levels and higher disease activity scores.

Keywords: plasminogen activator inhibitor-1, PAI-1, gene polymorphism, SLE, children, adolescents

\section{Introduction}

Childhood-onset systemic lupus erythematosus (cSLE) is a multifaceted autoimmune and inflammatory disease, accounts for about one in every five cases of SLE. ${ }^{1}$ cSLE diverse presentation range from mild cutaneous and articular involvement through nephritis, hematological or neuropsychiatric disorders to endstage renal disease [ESRD] and catastrophic thrombosis. ${ }^{2}$ More than $60 \%$ of childhood-onset cases develop lupus nephritis (LN) with approximately 
one-fourth of them proceed to ESRD. ${ }^{3}$ cSLE hallmark is multiple pathogenic autoantibody production with immune-mediated inflammation and tissue injury. ${ }^{4}$ The disruption of dynamic balance between the coagulation cascade and fibrinolysis pathway have been linked with an increased tendency to glomerular microthrombosis in a subset of patients with LN. ${ }^{5,6}$ Recent studies have focused on molecules residing at the nexus between thrombosis and inflammatory processes as potential candidate for SLE susceptibility and phenotype presentation or disease progression. ${ }^{7}$

Among these molecules, plasminogen activator inhibitor-1 (PAI-1) is a member of the serpin protease family and serves as the major inhibitor of endogenous fibrinolysis pathway. It is mainly synthesized by endothelial cells, adipocytes and platelets. ${ }^{8}$ PAI-1 can bind to and inhibit both tissue-type (t-PA) and urokinase-type (u-PA) plasminogen activators. Thus, PAI-1 reduces the conversion of plasminogen to plasmin, the main enzyme involved in fibrinolysis. ${ }^{9}$

A more recent study by Li et al suggested that impaired fibrinolysis contributes to a hypercoagulability state and microthrombotic events in Chinese pediatric cohort with SLE as demonstrated by increased levels of PAI-1 and decreased levels of t-PA. ${ }^{10}$

A recent meta-analysis by Bae et al reported significant up-regulation of circulating PAI-1 levels in multi-ethnic cohorts with adult-onset SLE. ${ }^{11}$ In murine lupus models, PAI-1 was highly expressed throughout its inflamed kidneys and the level of PAI-1 in renal tissues was correlated with the severity of lupus nephritis. ${ }^{12}$ Despite these reports, a genetic approach could be the only way to explore the potential role of PAI-1 in etiopathogenesis of childhood-onset SLE and lupus nephritis.

Human PAI-1 is encoded by the SERPINE1 gene mapped to chromosome 7q21.3-q22.1 in which several polymorphisms have been discovered. ${ }^{13}$ A functional insertion/ deletion single nucleotide polymorphism (SNP) containing either four or five guanine bases $(4 \mathrm{G} / 5 \mathrm{G})$ in the PAI-1 gene promoter at the -675 position (rs1799889) was reported to modulate PAI-1 mRNA transcriptional activity and expression level. ${ }^{14}$ In vitro studies demonstrated that the $4 \mathrm{G}$ allele produces 6 times more PAI-1 mRNA expression than the $5 \mathrm{G}$ allele in response to interleukin (IL)-1B. ${ }^{15}$

In Caucasian population, the PAI-1 4G allele was found to be associated with approximately $25 \%$ higher plasma PAI-1 concentrations ${ }^{16}$ and may represent a susceptibility allele for autoimmune disorders including SLE. ${ }^{11}$ Given the sparse data on PAI-1 in the context of pediatric lupus, we aimed to investigate whether the PAI- $1(4 \mathrm{G} / 5 \mathrm{G})$ promoter polymorphism at the -675 position could be a genetic marker for cSLE susceptibility or development of lupus nephritis in Egyptian children and adolescents. In addition, we assessed variations in PAI-1 serum levels related to the PAI-1 (4G/5G) polymorphism.

\section{Methods}

This multicenter case-control study was carried out at Helwan, Zagazig, Cairo, and Sohag University hospitals and outpatient clinics at the same hospitals. The study protocol was approved by medical ethics committee at Helwan, Zagazig, Cairo and Sohag Universities, Egypt. Written informed parental consent was provided for all participants conformed to the Declaration of Helsinki.

Three hundred fifty unrelated patients with onset of SLE before 18 years of age who fulfilled at least 4 of revised American College of Rheumatology SLE classification criteria, ${ }^{17}$ were enrolled from April 2017 to May 2020. All patients were newly diagnosed SLE cases. Detailed demographic data, age at diagnosis of SLE, cumulative clinical features, laboratory findings, and duration of follow-up were recorded. Medications used at the study time were also recorded (intravenous methylprednisolone pulses, prednisone, hydroxychloroquine sulfate (HCQ) and immunosuppressive agents ie, intravenous cyclophosphamide, mycophenolate mofetil, azathioprine, and cyclosporine). Disease activity and flare scoring was calculated according to the revised SLEDAI-2000 (2K) modification. ${ }^{18}$ Routine laboratory tests were investigated at study entry including complete blood count $(\mathrm{CBC})$, urine analysis, urine protein/creatinine ratio, complements $\mathrm{C} 3$ and $\mathrm{C} 4$, antinuclear antibodies (ANA), antibodies to double-stranded DNA (anti-ds DNA) titer, anti-phospholipid antibodies, and lupus anticoagulant. Patients with clinically evident LN underwent diagnostic percutaneous ultrasound-guided renal biopsy before the start of treatment. Renal histopathology was classified by expert pathologist (ETE) according to guidelines published by the International Society of Nephrology/Renal Pathology Society for evaluation and scoring of LN. ${ }^{19}$

\section{Exclusion Criteria}

Patients were excluded if they met criteria for other autoimmune disease, renal disease other than lupus-related nephritis, and those on dialysis. Patients diagnosed with 
anti-phospholipid syndrome, primary hematologic or liver disease, severe infectious illness and any other comorbidity were also excluded.

The control population comprised 350 unrelated healthy children and adolescents, of matched age and gender; who attended for routine checkup at outpatient clinics of the study hospitals. Both patient and control groups belong to the same ethnicity; African-Caucasian. For all subjects, $3 \mathrm{~mL}$ whole blood samples were withdrawn at 08.00 A.M. after an overnight fast to avoid the diurnal variation in PAI-1 serum level. ${ }^{20}$

\section{Serum PAI-I Assay}

Serum PAI-1 concentrations were assayed using Immuno Quantitative ELISA kit (RayBio $^{\circledR}$ Human PAI-1 IQELISA $^{\text {TM }}$ Kit, GA 30,092, USA) using a standard curve with detection range: $3.01 \mathrm{pg} / \mathrm{mL}$ to $12,500 \mathrm{pg} / \mathrm{mL}$ and sensitivity: $3.01 \mathrm{pg} / \mathrm{mL}$.

\section{Genomic DNA Extraction}

The Gene JET kit was used to extract the DNA from 200 $\mu \mathrm{L}$ of whole blood (Genomic DNA Purification Mini Kit, Thermo Scientific, USA) and stored at $-20^{\circ} \mathrm{C}$ for genotyping.

\section{Genotyping}

We genotyped all subjects for the PAI-1 promoter $4 \mathrm{G} / 5 \mathrm{G}$ polymorphism at position - 675 (rs1799889) by PCRrestriction fragment length polymorphism (RFLP) method. The sense primer 5'-CAC AGA GAG AGT CTG GCC ACGT-3' and the antisense primer 5'-CCA ACA GAG GAC TCT TGG TCT-3' were used as described by Rossaak et al. ${ }^{21}$ The PCR products were a 99 base pair (bp) for the $5 \mathrm{G}$ allele and a $98 \mathrm{bp}$ for the $4 \mathrm{G}$ allele. The amplified DNA was digested with restriction endonuclease enzyme Bsl I (New England Biolabs) at $37{ }^{\circ} \mathrm{C}$ for 90 minutes and then, analyzed by electrophoresis in a $3 \%$ agarose gel after staining with ethidium bromide. Digestion fragments of 77 and $22 \mathrm{bp}$ correspond to the (5G/5G); fragment 98 bp corresponds to the $(4 \mathrm{G} / 4 \mathrm{G})$; and fragments of $98,77,22 \mathrm{bp}$ correspond to the $(4 \mathrm{G} / 5 \mathrm{G})$ genotypes; Figure 1.

\section{Statistical Analysis}

The appropriate sample size was determined using PAWE3D; together with the specific study design, hypothesis, inheritance model, allele frequency, and allowable error rates; to detect variant allele frequency of 0.05 and

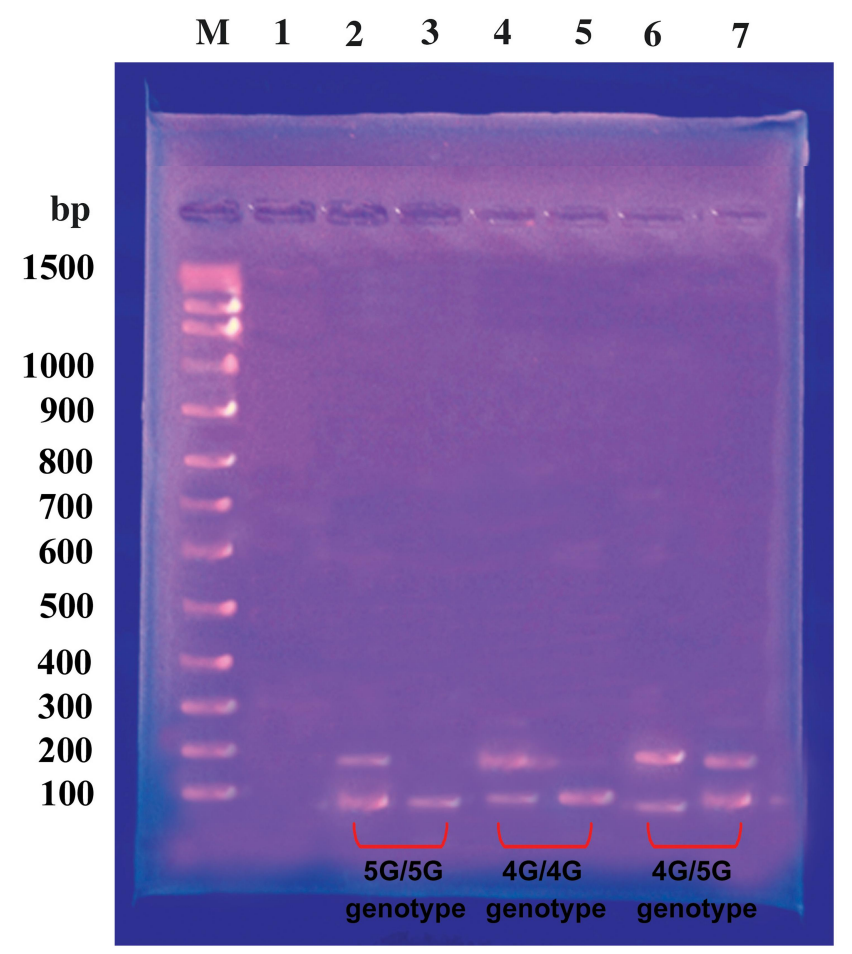

Figure I Gel electrophoresis of PCR products. Lane I; 100-bp marker; lane 2, 3 represent the $5 G / 5 G$ genotype; lane 4,5 represent the $4 G / 4 G$ genotype; and lane 6 , 7 represent the $4 G / 5 G$ genotype.

genotype relative risk of $\geq 1.8$ at $80 \%$ power. The Chisquare $(\chi 2)$ test was applied to estimate the HardyWeinberg equilibrium (HWE) and to compare PAI-1 (4G/ $5 \mathrm{G})$ genotype frequencies between the patient and control groups. Logistic regression analysis was performed to assess possible associations between PAI-1 (4G/5G) genotypes and lupus nephritis, SLEDAI score and PAI- 1 serum levels. Odds ratios and their 95\% confidence intervals [OR; 95\% CI] were calculated. Continuous parameters were compared with unpaired Student's $t$-test or one-way analysis of variance (ANOVA) test, as required. $\mathrm{P}<0.05$ was considered statistically significant. Statistical analysis was performed using SPSS package, version 18.0 (SPSS, Inc., Chicago, IL)

\section{Results}

Over the 3-year study period, 350 patients with definite c-SLE diagnosis and 350 healthy controls were enrolled. The mean age of patients was $(11.7 \pm 3.4)$ years and 332 $(94.8 \%)$ were females with a disease duration of (mean, $4.7 \pm 1.6)$ years. Control subjects were well-matched for age, gender and ethnicity [mean age (11.2 \pm 2.8$)$ years, 330 (94.2\%) were females; all $P>0.05$; Table 1]. 
Table I Baseline Demographic, Clinical and Laboratory Data of Patients with cSLE and Control Group

\begin{tabular}{|l|l|l|l|}
\hline & $\begin{array}{l}\text { Patients } \\
\text { n=350 (\%) }\end{array}$ & $\begin{array}{l}\text { Controls } \\
\text { n=350 (\%) }\end{array}$ & P \\
\hline Age(mean \pm SD years) & $11.7 \pm 3.4$ & $11.2 \pm 2.8$ & $0.403^{\mathrm{a}}$ \\
Gender(male/female) & $18 / 332$ & $20 / 330$ & $0.186^{6}$ \\
Age at diagnosis & $9.6 \pm 2.8$ & NA & \\
Disease duration (years) & $4.7 \pm 1.6$ & - & \\
Malar rash, n(\%) & $151(43)$ & - & \\
Photosensitivity, n(\%) & $122(35)$ & - & \\
Oral ulcers, n(\%) & $105(30)$ & - & \\
Discoid rash, n(\%) & $56(16)$ & - & \\
Alopecia, n(\%) & $91(26)$ & - & \\
Arthritis, n(\%) & $133(38)$ & - & \\
Serositis, n(\%) & $77(22)$ & - & \\
Neuropsychiatric disorders, n(\%) & $38(11)$ & - & \\
Hemolytic anemia & $189(54)$ & - & \\
Thrombocytopenia & $108(31)$ & - & \\
Leukopenia & $63(18)$ & & \\
Positive ANA, n (\%) & $343(98)$ & - & \\
Positive Anti-ds DNA, n(\%) & $326(93)$ & - & \\
Lupus nephritis, n(\%) & $24 I(69)$ & - & \\
\hline LN histologic grading & & & \\
I & $29(12)$ & - & \\
II & $55(23)$ & & \\
III & $89(37)$ & - & \\
IV & $68(28)$ & & \\
\hline Medications & $350(100)$ & - & \\
I. Prednisolone & $290(83)$ & & \\
II. HCQ & $336(96)$ & - & \\
III. Immunosuppressive therapy & $6.8 \pm 1.5$ & & \\
SLEDAI-2K score & & \\
\hline
\end{tabular}

Notes: Values in parentheses are percentages or data are presented as mean \pm SD.

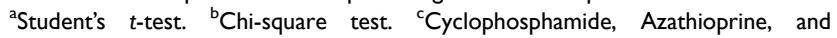
Mycophenolate mofetil.

Abbreviations: cSLE, childhood-onset systemic lupus erythematosus; ANA, antinuclear antibody; Anti-ds DNA, anti-double-stranded DNA antibody; LN, lupus nephritis; SLEDAI-2K, systemic lupus erythematosus Disease Activity Index; $\mathrm{HCQ}$, hydroxychloroquine.

Baseline demographics, laboratory data and clinical parameters for patients and control group are listed in Table 1. The most frequent clinical presentations of c-SLE were active lupus nephritis (69\%), pallor (54\%), and malar rash (43\%). Seropositive Anti-ds DNA and ANA were reported in $93 \%$ and $98 \%$ of patients, respectively, Table 1. Among 241 patients with LN, ISN/RPS class III was the most frequent (37\%) followed by class IV (28\%); Table 1.

The PAI-1 4G/5G genotype distribution and allele frequency in patients and control group were conformed to the Hardy-Weinberg equilibrium and are summarized in Table 2. The PAI-1 4G/4G genotype at position - 675 was more represented in c-SLE patients, as compared to the control group ( $38 \%$ vs. $23 \%$, respectively). Patients who were homozygotes for the PAI-1 4G/4G had 2.7- fold increased susceptibility to c-SLE (OR $=2.7 ;[95 \% \mathrm{CI}$ : 1.47-2.9]; $P<0.001$ ); Table 2. Besides, PAI-1 $4 \mathrm{G}$ allele at the same position was significantly more frequent among studied patients compared to control children (60\% vs 51\%; OR: 1.45 ; [95\% CI: $1.2-1.8]$; $P<0.01$ ); Table 2 .

We found that patients carrying the PAI- $14 \mathrm{G} / 4 \mathrm{G}$ genotype or 4G allele were more likely to develop lupus nephritis (OR: 3.38; [95\% CI: 1.9-5.9]; $P<0.001$, for the 4G/4G genotype and OR: 2.6; [95\% CI: 1.85-3.67]; for the $4 \mathrm{G}$ allele; $P<0.01$ ), Table 3 . In addition, PAI-1 $4 \mathrm{G}$ homozygotes tend to have a more active disease as demonstrated by higher SLEDAI-2K scores $(P=0.02)$; Table 4 . However, our data did not support a significant association between the PAI-1 4G/5G polymorphism and other clinical presentations or laboratory parameters of SLE among studied patients (all $P>0.05$; Table 4).

Of note, c-SLE patients had significantly higher mean PAI-1 serum concentrations than did control group (47.8 $\pm 6.9 \mathrm{ng} / \mathrm{mL}$ vs $18.6 \pm 5.7 \mathrm{ng} / \mathrm{mL}$, respectively; $P=0.003$ ); Table 2, Figure 2.

Moreover, patients with LN did have significantly higher PAI-1 serum levels compared to those without LN (mean; $68.5 \pm 11.4 \mathrm{ng} / \mathrm{mL}$ vs $43.6 \pm 9.2 \mathrm{ng} / \mathrm{mL}$, respectively; $P=0.02)$; Table 3 .

Patients carrying the PAI-1 4G/4G genotype had significantly higher PAI-1 serum concentrations (mean; 86.6 $\pm 22.7 \mathrm{ng} / \mathrm{mL}$ ) as compared to intermediate levels for those with a $4 \mathrm{G} / 5 \mathrm{G}$ genotype (mean; $48.3 \pm 16.5 \mathrm{ng} / \mathrm{mL}$ ) and the lowest for the $5 \mathrm{G} / 5 \mathrm{G}$ genotype (mean; $34.7 \pm 11.4 \mathrm{ng} / \mathrm{mL}$ ), respectively; $P=0.004$; Table 5 . The mean PAI-1 serum level for the $4 \mathrm{G}$ allele was $(74.8 \pm 18.9 \mathrm{ng} / \mathrm{mL})$ vs $(32.5$ $\pm 14.6 \mathrm{ng} / \mathrm{mL} ; P=0.01$ ) for the $5 \mathrm{G}$ allele at the same position; Table 5.

Interestingly, healthy controls with the $4 \mathrm{G} / 4 \mathrm{G}$ genotype were also found to have the highest PAI-1 serum levels (mean; $35.4 \pm 8 \mathrm{ng} / \mathrm{mL}$ ), compared with those carrying the $4 \mathrm{G} / 5 \mathrm{G}$ or $5 \mathrm{G} / 5 \mathrm{G}$ genotype (mean; $21.5 \pm 4.9$ and $16.8 \pm 5.7 \mathrm{ng} / \mathrm{mL}$, respectively; $P=0.01$ ); Table 5 .

\section{Discussion}

Recent studies have linked the PAI-1 4G/5G polymorphism with a variety of human diseases such as meningococcal disease, sepsis, obesity, metabolic syndrome, 
Table 2 Distribution of PAI-I (4G/5G) Genotypes, and Allele Frequency in Patients with c-SLE and Control Group

\begin{tabular}{|c|c|c|c|c|c|c|c|}
\hline \multirow[t]{2}{*}{ Model } & \multirow[t]{2}{*}{ Genotype } & \multicolumn{2}{|c|}{ Patient group } & \multicolumn{2}{|c|}{ Control group } & \multirow[t]{2}{*}{ OR(95\% Cl) } & \multirow[t]{2}{*}{$P$} \\
\hline & & $n(350)$ & $\%$ & $n(350)$ & $\%$ & & \\
\hline \multirow[t]{3}{*}{ Co-dominant } & $5 G / 5 G$ & 63 & $(18)$ & 74 & (2I) & Referent & \\
\hline & $4 \mathrm{G} / 5 \mathrm{G}$ & 154 & (44) & 196 & (56) & $0.92(0.6 I-I .4)$ & 0.768 \\
\hline & $4 \mathrm{G} / 4 \mathrm{G}$ & 133 & (38) & 80 & (23) & $2.7(1.47-2.9)$ & $<0.001$ \\
\hline \multirow[t]{2}{*}{ Alleles } & $5 G$ & 280 & (40) & 344 & (49) & Referent & \\
\hline & $4 \mathrm{G}$ & 420 & $(60)$ & 356 & (5I) & $1.45(1.2-1.8)$ & $<0.01$ \\
\hline \multirow[t]{2}{*}{ Dominant } & $5 G / 5 G$ & 63 & (I8) & 74 & (2I) & Referent & \\
\hline & $4 G / 5 G+4 G / 4 G$ & 287 & $(82)$ & 276 & (79) & I. $2(0.83-I .8 I)$ & 0.295 \\
\hline \multirow[t]{2}{*}{ Recessive } & $5 G / 5 G+4 G / 5 G$ & 217 & (62) & 270 & (77) & Referent & \\
\hline & $4 \mathrm{G} / 4 \mathrm{G}$ & 133 & (38) & 80 & (23) & $1.95(1.23-3.09)$ & 0.002 \\
\hline \multirow[t]{2}{*}{ Over-dominant } & $5 G / 5 G+4 G / 4 G$ & 196 & (56) & 154 & (44) & Referent & \\
\hline & $4 \mathrm{G} / 5 \mathrm{G}$ & 154 & (44) & 196 & (56) & $0.62(0.84-I .23)$ & 0.354 \\
\hline Serum PAI-I (ng/ml) & & \multicolumn{2}{|l|}{$47.8 \pm 6.9$} & \multicolumn{2}{|c|}{$18.6 \pm 5.7$} & \multicolumn{2}{|l|}{$0.003^{\mathrm{a}}$} \\
\hline
\end{tabular}

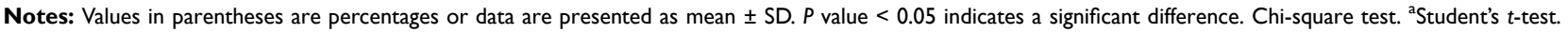
Abbreviations: OR, odds ratio; $\mathrm{Cl}$, 95\% confidence interval; PAI-I, plasminogen activator inhibitor-I; cSLE, childhood-onset systemic lupus erythematosus.

Table 3 Association of the PAI-I 4G/5G Genotypes and Alleles with Lupus Nephritis in Patients with Childhood-Onset SLE

\begin{tabular}{|c|c|c|c|c|c|}
\hline \multirow[t]{3}{*}{ Genotype } & & \multicolumn{2}{|c|}{ Lupus Nephritis } & \multirow[t]{3}{*}{ OR(95\% Cl) } & \multirow[t]{3}{*}{$P$} \\
\hline & & Presence & Absence & & \\
\hline & & $n(24 I) \%$ & $n(109) \%$ & & \\
\hline \multirow[t]{3}{*}{ PAI-I (-675) } & $5 G / 5 G$ & $28(12)$ & $35(32)$ & Referent & \\
\hline & $4 G / 5 G$ & $102(42)$ & $52(48)$ & $0.80(0.5-1.3)$ & 0.347 \\
\hline & $4 \mathrm{G} / 4 \mathrm{G}$ & III (46) & $22(20)$ & $3.38(1.9-5.9)$ & $<0.001$ \\
\hline \multirow[t]{2}{*}{ Alleles } & $5 G$ & $158(33)$ & $122(56)$ & Referent & \\
\hline & $4 G$ & $324(67)$ & $96(44)$ & $2.6(1.85-3.67)$ & $<0.01$ \\
\hline Serum PAI-I (ng/mL) & & $68.5 \pm 11.4$ & $43.6 \pm 9.2$ & & $0.02^{\mathrm{a}}$ \\
\hline
\end{tabular}

Notes: Values in parentheses are percentages or data are presented as mean \pm SD. $P$ value $<0.05$ indicates a significant difference. Chi-square test. ${ }^{a}$ Student's $t$-test. Abbreviations: SLE, systemic lupus erythematosus; PAI-I, plasminogen activator inhibitor-I; OR, odds ratio; CI, $95 \%$ confidence interval.

cancer, primary nephrotic syndrome, and autoimmune disorders. $^{11,22-26}$

To the best of the authors' knowledge, ours is the first such study to investigate $P A I-14 G / 5 G$ polymorphism in Caucasian children and adolescents with SLE.

In this study, the PAI-1 $4 G$ allele and 4G/4G homozygous genotype at position - 675 were significantly more represented among SLE patients compared to the control group. In addition, we found that the PAI-1 $4 \mathrm{G}$ allele and $4 \mathrm{G} / 4 \mathrm{G}$ genotype at the same position may constitute risk factors for developing lupus [OR: 1.45 and 2.7, respectively] and lupus nephritis [OR: 2.6 and 3.38, respectively]. Moreover, we observed that the PAI-1 4G/4G genotype was associated with a more active disease as demonstrated by higher SLEDAI-2K score among studied patients. However, no significant association was evident between the PAI-1 4G/5G SNP and other clinical phenotypes or laboratory profile of SLE. To date, only few studies in the literature investigated the PAI-1 4G/5G polymorphism in SLE adult patients with conflicting results. 
Table 4 Association of the PAI-I (4G/5G) Genotypes with Clinical, and Laboratory Features in Patients with ChildhoodOnset SLE

\begin{tabular}{|c|c|c|c|c|}
\hline \multirow[t]{2}{*}{$\begin{array}{l}\text { PAI-I (-675) } \\
\text { Genotype }\end{array}$} & $\begin{array}{l}5 G / 5 G \\
(n=63)\end{array}$ & $\begin{array}{l}4 G / 5 G \\
(n= \\
154)\end{array}$ & $\begin{array}{l}\text { 4G/4G } \\
(n=133)\end{array}$ & \multirow[t]{2}{*}{$P$} \\
\hline & n (\%) & n (\%) & n (\%) & \\
\hline $\begin{array}{l}\text { Age at } \\
\text { diagnosis(years) }\end{array}$ & $11.4 \pm 2.6$ & $1 \mathrm{I} \pm 1.8$ & $10.8 \pm 2.5$ & $0.375^{a}$ \\
\hline Malar rash & $32(50.7)$ & $83(53.8)$ & $74(55.6)$ & 0.164 \\
\hline Photosensitivity & $21(33)$ & $54(35)$ & $47(35)$ & 0.092 \\
\hline Discoid rash & $10(15.8)$ & $24(15.5)$ & $22(16.5)$ & 0.381 \\
\hline Alopecia & $16(25)$ & $39(25)$ & $36(27)$ & 0.642 \\
\hline Arthritis & $33(52)$ & $78(5 \mathrm{I})$ & $68(5 \mathrm{I})$ & 0.432 \\
\hline Oral ulcers & $19(30)$ & $43(28)$ & $43(32)$ & 0.706 \\
\hline Serositis & $14(22)$ & $32(20.7)$ & $31(23)$ & 0.529 \\
\hline $\begin{array}{l}\text { Neuropsychiatric } \\
\text { disorders }\end{array}$ & $7(\mathrm{II})$ & $16(10)$ & $15(11)$ & 0.312 \\
\hline Hematologic disorder & $47(74.6)$ & $113(73)$ & $99(74)$ & 0.824 \\
\hline Immunologic disorder & $61(97)$ & $146(95)$ & $129(97)$ & 0.127 \\
\hline SLEDAI-2K & $4.8 \pm 1.3$ & $5.3 \pm 0.8$ & $11.6 \pm 2.4 \dagger$ & $0.02^{\mathrm{a}}$ \\
\hline
\end{tabular}

Notes: Values in parentheses are percentages or data are presented as mean \pm SD. $P$ value $<0.05$ indicates a significant difference. Chi-square test. ${ }^{a}$ ANOVA test. †Significant difference between each three genotypes group.

Abbreviations: SLE, systemic lupus erythematosus; PAI-I, plasminogen activator inhibitor-I; ANA, antinuclear antibody; SLEDAI-2K, systemic lupus erythematosus Disease Activity Index.

Anaya-Macias et al reported that the PAI-1 4G/4G genotype and $4 \mathrm{G}$ allele were identified as genetic markers for increased susceptibility to SLE in Mexican-Mestizo population. ${ }^{27}$ Eldeeb et al studied the PAI-1 4G/5G SNP on genomic DNA of 170 Egyptian patients with adult-onset SLE. The authors concluded that the PAI-1 4G homozygote was identified as a risk factor for developing proliferative LN. ${ }^{28}$

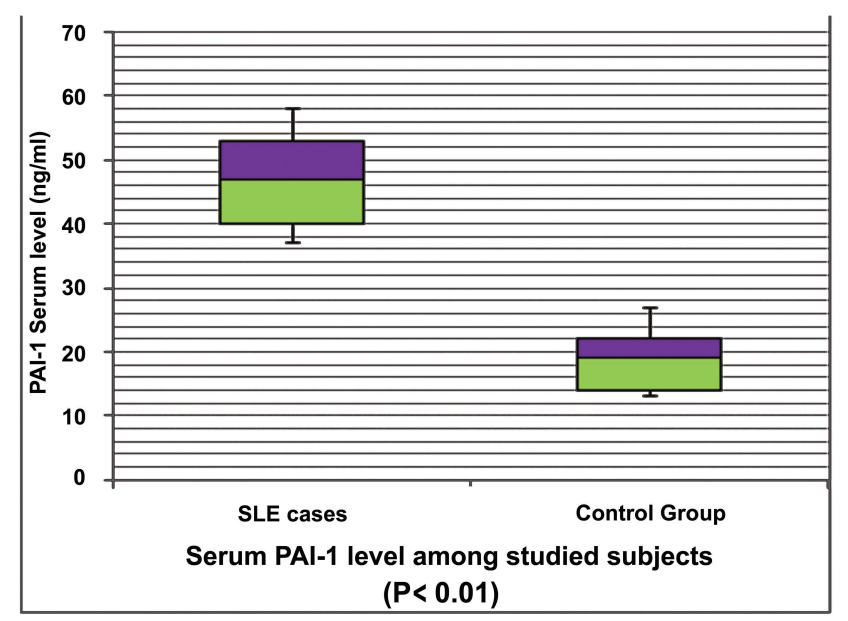

Figure 2 PAI-I serum levels in SLE patients and control group.
Table 5 Comparison of PAI-I Serum Levels in Patients with Childhood-Onset SLE and Control Group with Various PAI-I (4G/5G) Genotypes and Alleles

\begin{tabular}{|c|l|l|l|l|}
\hline \multirow{2}{*}{$\begin{array}{l}\text { PAI-I (4G/5G) } \\
\text { Genotype }\end{array}$} & \multicolumn{3}{|l|}{ Serum PAI-I (ng/mL) } \\
\cline { 2 - 5 } & $\begin{array}{l}\text { SLE } \\
\text { Patients }\end{array}$ & $P$ & $\begin{array}{l}\text { Control } \\
\text { Group }\end{array}$ & $P$ \\
\hline PAI-I (-675) & & & & \\
$5 G / 5 G$ & $34.7 \pm 11.4$ & & $16.8 \pm 5.7$ & \\
$4 G / 5 G$ & $48.3 \pm 16.5$ & & $21.5 \pm 4.9$ & \\
$4 G / 4 G$ & $86.6 \pm 22.7 \dagger$ & $0.004^{\mathrm{a}}$ & $35.4 \pm 8 \dagger$ & $0.01^{\mathrm{a}}$ \\
\hline Allele & & & & \\
$5 G$ & $32.5 \pm 14.6$ & & $18.2 \pm 4.4$ & \\
$4 G$ & $74.8 \pm 18.9$ & $0.0 I^{\mathrm{b}}$ & $34.6 \pm 7.6$ & $0.03^{\mathrm{b}}$ \\
\hline
\end{tabular}

Notes: Data are presented as mean \pm SD. $P$ value $<0.05$ indicates a significant difference. $\dagger$ Significant difference between each three genotypes group. ${ }^{a}$ ANOVA test. 'Student's t-test.

Abbreviations: PAI-I, plasminogen activator inhibitor-I; SLE, systemic lupus erythematosus.

Wang et al reported that the PAI-1 4G/4G genotype could predict higher nephritis activity, and more extensive necrotizing lesions without genetic association to the development of SLE or LN in Chinese population. ${ }^{29}$ Bates et al detected the presence of anti-PAI-1 autoantibodies in a cohort of British SLE patients, correlated with both anti-double stranded DNA (ds DNA) autoantibody titer and the disease activity index scores. $^{30}$

In contrast, previous studies did not identify any association between the PAI-1 4G/5G polymorphism and lupus susceptibility or its clinical expression in Russian, Bulgarian, Spanish, and Argentinean SLE cohorts with adult-onset disease. ${ }^{31-34}$ Similarly, a recent meta-analysis of nine studies demonstrated that the PAI-1 4G/5G polymorphism did not increase the risk of SLE or LN among Asian and European populations, although they reported significant up-regulation of circulating PAI-1 activity in multi-ethnic cohorts with adult-onset SLE. ${ }^{11}$

Ethnic background or gene-environmental interplay as well as differences in cohort size and studied age group may partly explain these discrepancies between our study and previously published data.

PAI-1 is an acute phase protein regulated by inflammatory cytokines, chemokine, growth factors, hormones, and bacterial endotoxins. ${ }^{8}$ PAI-1 is also unique among serpins superfamily as it is expressed by various cell types and has multiple molecular interactions. ${ }^{8,9}$ PAI- 1 resides at a key site in the fibrinolysis pathway and its overexpression compromises fibrin clearance, thus promoting microthrombosis. 6,7 PAI-1 is also up-regulated by pro-inflammatory cytokines 
such as interleukin-6, IL-1 $\beta$, tumor necrosis factor- $\alpha$, and tissue growth factor- $\beta$. Moreover, PAI-1 enhances inflammation and cytokines release in a cyclic manner and may be a biological parameter for an ongoing inflammatory process. $^{35}$ The PAI-1 activity has also been shown to inhibit apoptosis in different cell lines which may contribute to tolerance breakdown and autoimmunity. ${ }^{36}$ Therefore, this molecule exhibits a unique role in many pathophysiologic processes such as thrombosis, inflammation and apoptosis which may represent different scenarios for PAI-1 contribution in SLE pathogenesis.

In an attempt to explain our findings, we investigated PAI-1 serum concentrations in patients with SLE which were significantly higher than did healthy control group. Moreover, patients with LN had increased mean serum PAI-1 concentrations as compared to those without nephritis. These findings confirm and extend the results of previous studies in Turkish, Indian and Brazilian cohorts with adult-onset SLE. ${ }^{37-39}$

In this study, we speculate that the PAI-1 4G/5G SNP may alter PAI-1 expression level as we observed that the $5 \mathrm{G}$ to $4 \mathrm{G}$ switch at -675 position was associated with increased PAI-1 serum concentrations among studied subjects and the PAI-1 5G/5G, 5G/4G, and 4G/4G genotypes were associated with low, intermediate, and high PAI-1 serum levels, respectively. Consistent with these findings, previous studies have explained that the deletion of the PAI 4G allele (only 4 guanine bases) has been associated with the inability to bind a repressor protein that decreases binding of the transcriptional activator, resulting in up to 6 times more PAI-1 mRNA expression and increased circulating PAI-1 levels. ${ }^{15,40}$

The PAI-1/t-PA dynamic balance is involved in fibrin deposition in glomeruli, and extracellular matrix turnover. PAI-1 mRNA levels were found to be strongly upregulated in murine $\mathrm{LN}$ models, meanwhile treatment with anti-PAI-1 monoclonal antibody provided protection against the pathological changes in its kidneys. ${ }^{12,41}$ Elevated PAI-1 circulating levels have been reported to be one of the major reasons for impaired fibrinolysis and a hypercoagulability state that promote thrombosis in patients with SLE. ${ }^{42}$ Gong et al reported that the PAI-1 4G/4G genotype predispose to glomerular microthrombosis in LN patients. ${ }^{6,7}$ Consistent with our view, the authors explained that PAI-1 4G homozygotes tend to have higher PAI-1 serum concentrations; therefore, their fibrinolytic activity was blunted. Glomerular microthrombosis could incite and aggravate renal inflammation and perpetuate the lupus-induced kidney destruction, thus worsen renal dysfunction. ${ }^{7}$ It remains unclear if the PAI-1 $4 \mathrm{G}$ allele enhances the phenotypic expression of thrombophilia in patients with cSLE. However, a sole causal relationship between the PAI-1 4G/5G SNP and the risk of glomerular microthrombosis in pediatric patients with LN should be investigated further.

Because PAI-1 is considered to be a risk factor for many human diseases, extensive research are underway to develop selective PAI-1 inhibitors either by the use of monoclonal antibodies or antisense oligonucleotides that can inhibit PAI1 synthesis, no such inhibitors are clinically applied yet.

Combining multi-ethnic population genomics with clinical profiling, and bioinformatics will provide new insights into biomarker development and novel targets for cSLE therapy.

Since PAI-1 serum level has a diurnal variation, a crosssectional measurement may constitute a possible limitation in this study. All included patients had SLEDAI score > 4; indicating active disease at the time of inclusion, so the effect of inflammation on PAI-1 serum levels; as one of acute phase reactants, could not be excluded. Also, we have studied a single $P A I-1$ gene polymorphism which may exhibit an epistatic interaction or linkage disequilibrium with $P A I-I$ genomic loci or complex haplotypes directly affecting PAI1 activity. Accordingly, genome-wide association studies are awaited across different ethnic populations to validate our findings.

\section{Conclusion}

The PAI-1 4G/5G polymorphism may confer susceptibility to childhood-onset SLE and development of lupus nephritis among Egyptian children and adolescents. Moreover, the PAI-1 4G/4G genotype and 4G allele were associated with higher PAI-1 serum levels and higher disease activity scores.

Finally, PAI-1 may be a promising biomarker and potential molecular target for novel therapeutics in autoimmune and inflammatory disorders such as childhood-onset SLE.

\section{Abbreviations}

SLE, systemic lupus erythematosus; cSLE, childhood-onset systemic lupus erythematosus; LN, lupus nephritis; ESRD, end stage renal disease; PAI-1, plasminogen activator inhibitor-1; t-PA, tissue type-plasminogen activator; U-PA, urokinase type-plasminogen activator; ELISA, enzyme-linked immunosorbent assay; SNPs, single nucleotide polymorphisms; SLEDAI, Disease Activity Index; PCR-RFLP, polymerase chain reaction-restriction fragment length polymorphism; $\mathrm{OR}$, odds ratio; $\mathrm{CI}$, confidence interval. 


\section{Author Contributions}

All authors made a significant contribution to the work reported, whether that is in the conception, study design, execution, acquisition of data, analysis and interpretation, or in all these areas; took part in drafting, revising or critically reviewing the article; gave final approval of the version to be published; have agreed on the journal to which the article has been submitted; and agree to be accountable for all aspects of the work.

\section{Disclosure}

The authors report no conflict of interest in this work.

\section{References}

1. Klein-Gitelman M, Reiff A, Silverman\$146\#ED. Systemic lupus erythematosus in childhood. Rheum Dis Clin North Am. 2002;28 (3):561-577. doi:10.1016/S0889-857X(02)00015-7

2. Tsokos GC. Systemic lupus erythematosus. $N$ Engl $J$ Med. 2011;365:2110-2121.

3. Sato VA, Marques ID, Goldenstein PT, et al. Lupus nephritis is more severe in children and adolescents than in older adults. Lupus. 2012;21(9):978-983. doi:10.1177/0961203312443421

4. Choi J, Kim ST, Craft J. The pathogenesis of systemic lupus erythematosus-an update. Curr Opin Immunol. 2012;24(6):651-657. doi:10.1016/j.coi.2012.10.004

5. Kwaan HC, Nabhan C. Hereditary and acquired defects in the fibrinolytic system associated with thrombosis. Hematol Oncol Clin North Am. 2003;17:103-114. doi:10.1016/S0889-8588(02)00086-2

6. Gong R, Liu Z, Chen Z, Li L. Genetic variations in plasminogen activator inhibitor-1 gene and beta fibrinogen gene associated with glomerular microthrombosis in lupus nephritis and the gene dosage effect. Zhonghua Yi Xue Yi Chuan Xue Za Zhi. 2002;19:1-5.

7. Gong R, Liu Z, Li L. Epistatic effect of plasminogen activator inhibitor 1 and beta-fibrinogen genes on risk of glomerular microthrombosis in lupus nephritis: interaction with environmental/clinical factors. Arthritis Rheum. 2007;56:1608-1617. doi:10.1002/art.22598

8. De Taeye B, Smith LH, Vaughan DE. Plasminogen activator inhibitor-1: a common denominator in obesity, diabetes and cardiovascular disease. Curr Opin Pharmacol. 2005;5(2):149-154. doi:10. 1016/j.coph.2005.01.007

9. Fortenberry YM. Plasminogen activator inhibitor-1 inhibitors: a patent review (2006-present). Expert Opin Ther Pat. 2013;23 (7):801-815. doi:10.1517/13543776.2013.782393

10. Li Z, Xiao J, Song H, et al. Evaluation of coagulation disorders by thromboelastography in children with systemic lupus erythematosus. Lupus. 2019;28(2):181-188. doi:10.1177/0961203318819137

11. Bae SC, Lee YH. Association between plasminogen activator inhibitor-1 (PAI-1) 4G/5G polymorphism and circulating PAI-1 level in systemic lupus erythematosus and rheumatoid arthritis: a meta-analysis. Z Rheumatol. 2020;79(3):312-318. doi:10.1007/ s00393-019-00689-y

12. Keeton M, Ahn C, Eguchi Y, Burlingame R, Loskutoff DJ. Expression of type 1 plasminogen activator inhibitor in renal tissue in murine lupus nephritis. Kidney Int. 1995;47(1):148-157. doi:10.1038/ki.1995.17

13. Asselbergs FW, Pattin K, Snieder H, Hillege HL, van Gilst WH, Moore JH. Genetic architecture of tissue-type plasminogen activator and plasminogen activator inhibitor-1. Semin Thromb Hemost. 2008;34(6):562-568. doi:10.1055/s-0028-1103367
14. Dawson S, Hamsten A, Wiman B, Henney A, Humphries S. Genetic variation at the plasminogen activator inhibitor-1 locus is associated with altered levels of plasma plasminogen activator inhibitor-1 activity. Arterioscler Thromb. 1991;11(1):183-190. doi:10.1161/01. ATV.11.1.183

15. Dawson SJ, Wiman B, Hamsten A, Green F, Humphries S, Henney AM. The two allele sequences of a common polymorphism in the promoter of the plasminogen activator inhibitor-1 (PAI-1) gene respond differently to interleukin-1 in HepG2 cells. $J$ Biol Chem. 1993;268(15):10739-10745.

16. Burzotta F, Di Castelnuovo A, Amore C, et al. 4G/5G promoter PAI-1 gene polymorphism is associated with plasmatic PAI-1 activity in Italians: a model of gene-environment interaction. Thromb Haemost. 1998;79(2):354-358. doi:10.1055/s-0037-1614991

17. Petri M, Orbai AM, Alarcón GS, et al. Derivation and validation of the systemic lupus international collaborating clinics classification criteria for systemic lupus erythematosus. Arthritis Rheum. 2012;64 (8):2677-2686. doi:10.1002/art.34473

18. Yee CS, Farewell VT, Isenberg DA, et al. The use of systemic lupus erythematosus disease activity index-2000 to define active disease and minimal clinically meaningful change based on data from a large cohort of systemic lupus erythematosus patients. Rheumatology (Oxford). 2011;50(5):982-988. doi:10.1093/rheumatology/keq376

19. Weening JJ, D'Agati VD, Schwartz MM, et al. The classification of glomerulonephritis in systemic lupus erythematosus revisited. $J \mathrm{Am}$ Soc Nephrol. 2004;15(3):835-836.

20. Vaughan DE. PAI-1 and atherothrombosis. J Thromb Haemost. 2005;3(8):1879-1883. doi:10.1111/j.1538-7836.2005.01420.x

21. Rossaak JI, Van Rij AM, Jones GT, Harris EL. Association of the 4G/ $5 \mathrm{G}$ polymorphism in the promoter region of plasminogen activator inhibitor-1 with abdominal aortic aneurysms. J Vasc Surg. 2000;31 (5):1026-1032. doi:10.1067/mva.2000.104589

22. Geishofer G, Binder A, Müller M, et al. $4 \mathrm{G} / 5 \mathrm{G}$ promoter polymorphism in the plasminogen-activator-inhibitor-1 gene in children with systemic meningococcaemia. Eur J Pediatr. 2005;164(8):486-490. doi:10.1007/s00431-005-1673-4

23. Wingeyer SP, de Larrañaga G, Cunto E, Fontana L, Nogueras C, San Juan J. Role of $4 \mathrm{G} / 5 \mathrm{G}$ promoter polymorphism of Plasminogen Activator Inhibitor-1 (PAI-1) gene in outcome of sepsis. Thromb Res. 2010;125(4):367-369. doi:10.1016/j.thromres.2009.04.006

24. De la Cruz-mosso U, Muñoz-Valle JF, Salgado-Bernabé AB, et al. Body adiposity but not insulin resistance is associated with $-6754 \mathrm{G} /$ $5 \mathrm{G}$ polymorphism in the PAI-1 gene in a sample of Mexican children. J Pediatr (Rio J). 2013;89(5):492-498. doi:10.1016/j.jped.2013.01. 004

25. Pooyan H, Ahmad E, Azadeh R. $4 \mathrm{G} / 5 \mathrm{G}$ and A- $844 \mathrm{G}$ polymorphisms of plasminogen activator inhibitor-1 associated with glioblastoma in Iran-a Case-Control Study. Asian Pac J Cancer Prev. 2015;16 (15):6327-6330. doi:10.7314/APJCP.2015.16.15.6327

26. Luo $\mathrm{Y}$, Wang $\mathrm{C}, \mathrm{Tu} \mathrm{H}$. Impact of the $4 \mathrm{G} / 5 \mathrm{G}$ polymorphism in the plasminogen activator inhibitor-1 gene on primary nephrotic syndrome. Mol Med Rep. 2014;9(3):894-898. doi:10.3892/mmr.20 14.1903

27. Anaya-Macias BU, De la Cruz-mosso U, Palafox-Sánchez CA, et al. The $-6754 \mathrm{G} / 5 \mathrm{G}$ PAI-1 polymorphism confers genetic susceptibility to systemic lupus erythematosus, its clinical manifestations, and comorbidities in Mexican-Mestizo population. Autoimmunity. 2020;53(2):71-77. doi:10.1080/08916934.2019.1700957

28. Eldeeb AA, Sabry A, Yousef EA, Mahmoud R, Ibrahim AB, Alkhiary W. Plasminogen activator inhibitor-1 gene polymorphisms in systemic lupus erythematosus: is there a risk for lupus nephritis among Egyptians? JESNT. 2019;19(1):1-7.

29. Wang AY, Poon P, Lai FM, et al. Plasminogen activator inhibitor-1 gene polymorphism 4G/4G genotype and lupus nephritis in Chinese patients. Kidney Int. 2001;59(4):1520-1528. doi:10.1046/j.15231755.2001.0590041520.x 
30. Bates RL, Payne SJ, Drury SL, et al. The prevalence and clinical significance of autoantibodies to plasminogen activator inhibitor 1 in systemic lupus erythematosus. Lupus. 2003;12(8):617-622. doi:10.11 91/09612033031u436oa

31. Borisov EN, Krasnova TN, Samohodskaia LM, Ivanitskiǔ LV, Nikiforova NV, Mukhin NA. Prognostic value of allelic variants affecting the hemostatic system in the development of antiphospholipid syndrome and kidney lesion in patients with systemic lupus erythematosus. Ther Arch. 2014;86(6):57-62.

32. Savov A, Andonova S, Tanev D, et al. PAL-1 5G/4G polymorphism in patients with systemic lupus erythematosus. Akush Ginekol (Sofiia). 2014;53(7):13-17.

33. Tàssies D, Espinosa G, Muñoz-Rodríguez FJ, et al. The 4G/5G polymorphism of the type 1 plasminogen activator inhibitor gene and thrombosis in patients with antiphospholipid syndrome. Arthritis Rheum. 2000;43(10):2349-2358. doi:10.1002/1529-0131(200010)43:10<2349::AID-ANR24>3.0.CO;2-J

34. Muñoz SA, Aranda F, Allievi A, et al. $4 \mathrm{G} / 5 \mathrm{G}$ plasminogen activator inhibitor-1 and $-308 \mathrm{~A} / \mathrm{G}$ tumor necrosis factor- $\alpha$ promoter gene polymorphisms in Argentinean lupus patients: focus on lupus nephritis. Clin Exp Med. 2014;14(1):83-89. doi:10.1007/s10238-012-0221-6

35. Declerck PJ, Gils A. Three decades of research on plasminogen activator inhibitor-1: a multifaceted serpin. Semin Thromb Hemost. 2013;39(4):356-364.

36. Schneider DJ, Chen Y, Sobel BE. The effect of plasminogen activator inhibitor type 1 on apoptosis. Thromb Haemost. 2008;100 (6):1037-1040. doi:10.1160/TH08-04-0234
37. Bicakcigil M, Tasan D, Tasdelen N, Mutlu N, Yavuz S. Role of fibrinolytic parameters and plasminogen activator inhibitor 1 (PAI-1) promoter polymorphism on premature atherosclerosis in SLE patients. Lupus. 2011;20(10):1063-1071. doi:10.1177/096120 3311404911

38. Singh NK, Gupta A, Behera DR, Dash D. Elevated plasminogen activator inhibitor type-1 (PAI-1) as contributing factor in pathogenesis of hypercoagulable state in antiphospholipid syndrome. Rheumatol Int. 2013;33(9):2331-2336. doi:10.1007/s00296-0132717-0

39. da Rosa Franchi Santos LF, Stadtlober NP, Costa Dall'Aqua LG, et al. Increased adhesion molecule levels in systemic lupus erythematosus: relationships with severity of illness, autoimmunity, metabolic syndrome and cortisol levels. Lupus. 2018;27(3):380-388. doi:10.1177/0961203317723716

40. Eriksson P, Kallin B, van 'T Hooft FM, Båvenholm P, Hamsten A. Allele-specific increase in basal transcription of the plasminogen-activator inhibitor 1 gene is associated with myocardial infarction. Proc Natl Acad Sci U S A. 1995;92(6):1851-1855. doi:10.1073/pnas.92.6.1851

41. Hamano K, Iwano M, Akai Y, et al. Expression of glomerular plasminogen activator inhibitor type 1 in glomerulonephritis. Am J Kidney Dis. 2002;39(4):695-705. doi:10.1053/ajkd.2002.31986

42. Dhillon PK, Adams MJ. Thrombosis in systemic lupus erythematosus: role of impaired fibrinolysis. Semin Thromb Hemost. 2013;39 (4):434-440. doi:10.1055/s-0033-1334484
Journal of Inflammation Research

\section{Publish your work in this journal}

The Journal of Inflammation Research is an international, peerreviewed open-access journal that welcomes laboratory and clinical findings on the molecular basis, cell biology and pharmacology of inflammation including original research, reviews, symposium reports, hypothesis formation and commentaries on: acute/chronic inflammation; mediators of inflammation; cellular processes; molecular mechanisms; pharmacology and novel anti-inflammatory drugs; clinical conditions involving inflammation. The manuscript management system is completely online and includes a very quick and fair peerreview system. Visit http://www.dovepress.com/testimonials.php to read real quotes from published authors. 